Int. J. Dev. Biol. 50: 511-521 (2006)

doi: $10.1387 / \mathrm{ijdb} .052101 \mathrm{xn}$

Review

\title{
BMP signalling in craniofacial development
}

\author{
XUGUANG NIE*, KEIJO LUUKKO and PAIVI KETTUNEN \\ Section of Anatomy and Cell Biology, Department of Biomedicine, University of Bergen, Norway
}

CONTENTS

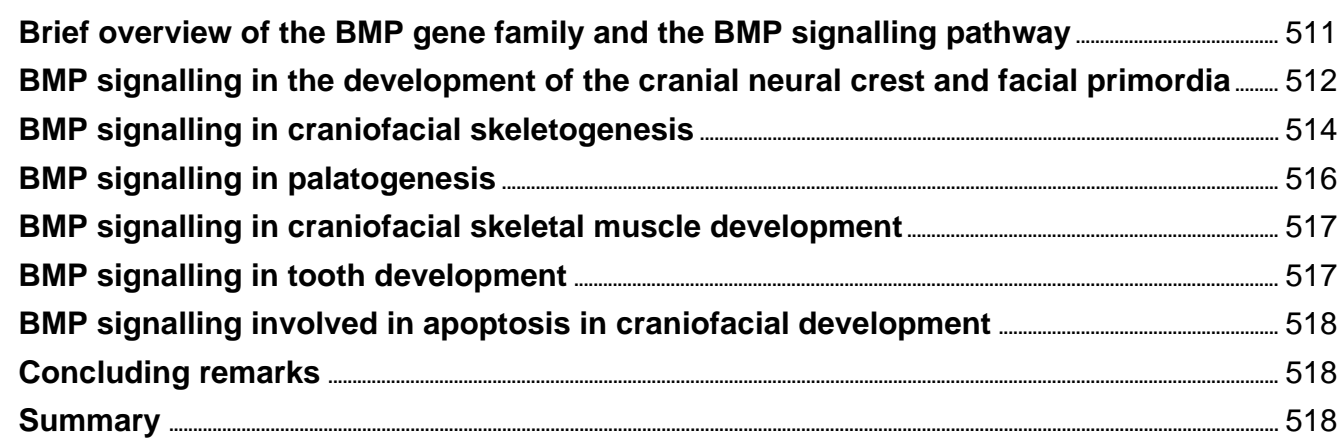

KEY WORDS: growth/differentiation factor, signalling, craniofacial development, abnormality

The head, comprising of the skull and the face, is the most anatomically sophisticated portion and evolutionary novelty in vertebrates. The most striking feature for the development of the vertebrate head is the emergence of the neural crest and its integration into the formation of craniofacial elements. The cranial neural crest, emerged from dorsal and lateral neural crest, contains multi-potent cells with high plasticity (Trainor et al., 2003). After specification, these cells undergo well orchestrated migration and eventually populate the branchial arches. Once they have reached their destinations, these cells proliferate and differentiate into specific cell types and give rise to a number of craniofacial elements through epithelial-mesenchymal interactions. In subsequent development, facial primordia undergo a quick outgrowth and midline union and eventually form a continuous face. These developmental processes are controlled by a complex genetic cascade that involves in a number of critical developmental genes such as members of the BMPfamily.

The presence of BMP was initially implicated by the pioneering work of Urist who first discovered bone autoinduction by bone matrix (Urist, 1965). Thereafter, a number of BMPs were isolated and cloned (Wozney et al., 1988). BMPs are now recognized as multifunctional growth factors that mediate a variety of biological functions essential for gastrulation, organogenesis and embryonic and postnatal growth. BMPs are also important participants in craniofacial development. How this conserved signal regulates the development of the phylogenetically new mammalian head remains an interesting and incompletely known issue. The use of mouse models and modern molecular techniques have greatly facilitated the process of craniofacial research and extended our understanding of craniofacial development in the past decade. The BMP signalling pathway has been shown to be involved in a number of developmental processes and critical for the formation of a variety of craniofacial elements including cranial neural crest, facial primordia, tooth, lip and palate. In the present review, the roles of BMP signalling in craniofacial development are discussed in detail, with a focus on recent advances.

\section{Brief overview of the BMP gene family and the BMP signalling pathway}

The $B M P$ gene family belongs to $T G F-\beta$ superfamily. Individually, members of this family are called either BMPS, osteogenic proteins (OP), cartilage derived morphogenetic protein (CDMP), or growth and differentiation factor (GDF). These members are divided into subfamilies based on phylogenetic analysis and sequence similarity. BMP2 and BMP4 are grouped as the $d p p$ subfamily because of their similarity to the ancestral $d p p$ gene

Abbreviations used in this paper: BMP, bone morphogenetic protein; CDMP, cartilage-derived morphogenetic protein; CNCC, cranial neural crest cell; GDF, growth and differentiation factor; NCC, neural crest cell; OP, osteogenic protein; r, rhombomere.

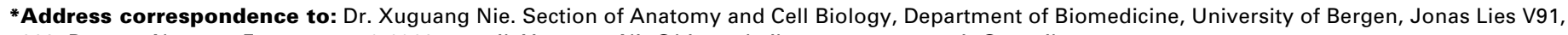
5009, Bergen, Norway. Fax: +47-5558-6360. e-mail: Xuguang.Nie@biomed.uib.no or xuguang.nie@gmail.com 
(decapentaplegic) of Drosophila, BMP5, -6, -7and -8are grouped as the 60A subfamily; BMP3 and BMP3b (GDF10) together constitute a unique subfamily; GDF5, $-6,-7$ constitute another subgroup in this family; Nodal and Lefty are distant members of the BMP subfamily. So far, more than 20 members have been identified in the BMP family (Kishigami and Mishina, 2005). In Tables 1 and 2, most of the Bmp members are listed. Additional members are continued to be identified. One of the BMPS, BMP1, does not belong to the TGFsuperfamily. In mice, Bmp1 encodes the most abundant protein of the bone extracellular matrix, a protease that releases the carboxy-terminal propeptide from the type I procollagen molecule. The members belong to the $d p p$ (BMP2, BMP4) and 60A subfamilies (BMP 5-8) have been extensively investigated in embryonic and postnatal development. This review only focuses on the important participants of craniofacial development.

BMPs mainly function through BMP receptor (BMPR) type I and type II (BMPRI and BMPRII). Three type I (ALK2, ALK3 or BMPRIA and ALK6 or BMPRIB) and three type II receptors (BRII, ActRIIA and ActRIIB) known to mediate the signal have been identified (Nohe et al., 2004). Generally, the type I receptors are the high-affinity binding receptors, whereas the type II receptors bind BMPs with low affinity. Binding of BMP to BMPR results in phosphorylation of downstream Smad proteins and thus triggers the intracellular signal cascade. The BMP signal activates Smad1, Smad5 and Smad8, which upon phosphorylation can associate with Smad4 (common Smad) into a heterodimeric complex that is further translocated to the nucleus where it activates transcription (Nohe et al., 2004). Smad6 and Smad7, on the other hand, are inhibitory to this signal transduction (Nohe etal., 2004). In addition to the Smad pathway, BMPs are believed to activate several different kinase pathways including MAPK, PI3 kinase and PKC (Kishigami and Mishina, 2005).

\section{BMP signalling in the development of the cranial neural crest and facial primordia}

Neural crest cells (NCCs) arise uniformly at the dorso-lateral edge of the closing neural folds along almost the entire length of the vertebrate embryo neuraxis, a region corresponds to the interface between the non-neural ectoderm and the neural plate. They are considered as stem-cell-like cells that show high plasticity (Trainor et al., 2003). After neurulation, NCCs delaminate and migrate along defined pathways to differentiate into a variety of cells and tissues. NCCs that are originated from the anterior neural tube (forebrain, midbrain and anterior hindbrain), called the cranial neural crest cells (CNCCs), populate the facial primordia and the pharyngeal arches and eventually differentiate into typical neural crest derivatives such as skeletons, neurons, cranial ganglions and connective tissues.

The formation of neural crest is a complex process that needs a cooperation of a number of critical signalling including the BMP, WNT and FGF pathways. The BMP signalling has long been recognized as a patterning signal for neural crest formation. It is found that Bmp4 and Bmp7are present in the ectoderm and can substitute for non-neural ectoderm for neural crest cell induction (Liem et al., 1995). Bmp4 is responsible for the maintenance of a variety of dorsal neural tube genes such as Msx1, Msx2 and Slug (Trainor et al., 2003, Tribulo et al., 2003) and a gradient of Bmp seems essential for specification of the neural plate and neural crest (Tribulo et al., 2003). In addition to the inductive role, Bmp signalling is also required for migration of CNCCs to the facial primordia (Kanzler et al., 2000, Knecht and Bronner-Fraser, 2002, Tribulo et al., 2003). Blocking of Bmp2/Bmp4 in mouse cranial neural crest by Xnoggin leads to depletion of CNCCs from the targeted areas; as a consequence, the branchial arches, normally populated by NCCs, are hypomorphic and their skeletal and neural derivatives fail to development (Kanzler et al., 2000).

During early craniofacial development, Bmp4, Bmp2and Bmp 7 are prominently expressed (Bennett et al., 1995, Francis-West et al., 1998, Francis-West et al., 1994). In the early facial primordia high epithelial expression of Bmp4 and Bmp 7 is associated with mesenchymal expression of Bmp2, MsX1 and MsX2 (Barlow and Francis-West, 1997, Bennett et al., 1995, Francis-West et al., 1998). Later, Bmp4 is also expressed in the mesenchyme of facial primordia (Barlow and Francis-West, 1997). Ectopic application of recombinant BMP2 or BMP4 also activates the expression of Msx genes at sites where normally do not have Msx expression (Barlow and Francis-West, 1997). This signalling cascade is correlated with altered expression of Fgf4 and Shh and leads to abnormal development of the facial primordia (Barlow and FrancisWest, 1997).

Unfortunately, conventional knockout approach on Bmpsdoes not reveal much information about the roles of Bmps in craniofacial development due to either early embryo death or functional redundancies among this family. For instance, deletion of $B m p 2$ or Bmp4, the prototypes of drosophila homologue (decapentaplegic), leads to early embryonic death around gastrulation in mice (Winnier et al., 1995, Zhang and Bradley, 1996), hampering the efforts to analyze their functions at late times; deletion of other members, however, does not show major defects in mouse craniofacial structures. Inactivation of Bmprs also leads to early lethality prior to craniofacial development (Beppu et al., 2000, Mishina et al., 1999, Mishina et al., 1995). Conditional knockout and double knockout approaches are more useful than conventional knockout. Mice deficient of $A / k 2$ in the neural crest $\left(A / k 2^{\text {nc- }}\right.$

${ }^{/-)}$or Bmprlafrom the facial primordia $\left(B m p r / a^{\text {fp-l- }}\right)$ show remarkable developmental anomalies in facial structures, implicating essential roles of Bmp signalling in a variety of developmental processes (Dudas et al., 2004, Liu et al., 2005). Bmp5/Bmp7 double mutants show underdevelopment of the branchial arches (Solloway and Robertson, 1999). Expression profiles of some Bmps and knockout phenotypes in mice are summarized in Tables 1 and 2.

Orofacial union is an important mechanism for craniofacial development. The facial primordia, palate and tongue all undergo a midline union in early development. Perturbation of this process leads to various orofacial clefts such as cleft lips, cleft palate, oblique facial cleft, lateral facial cleft, mandibular cleft and cleft tongue. Bmp signalling is a critical mediator in this process as indicated by $A / k$-deficient mice, in which orofacial cleft is one of the major anomalies (Dudas et al., 2004, Liu et al., 2005). Bmp4, which is highly expressed in the putative orofacial epithelia prior to facial union, is implicated as a good candidate for this role (Gong and Guo, 2003). A recently generated mouse model with inactivation of $B m p 4$ from facial primordia provides convincing evidence of this role (Liu et al., 2005). In those mice, the lip development is delayed and Fgf8, a critical gene for early facial 


\section{TABLE 1}

\section{BMP/BMPR CRANIOFACIAL EXPRESSION AND KNOCKOUT PHENOTYPES IN MICE AND RELATED DISORDERS}

\begin{tabular}{|c|c|c|}
\hline & Expression profiles in developing craniofacial structures & Phenotype of Knockout or loss-function mutants and related disorders \\
\hline Bmp2 & $\begin{array}{l}\text { Cranial neural crest, early facial primordia, skeletal } \\
\text { precursor, hypertrophic chondrocytes, dental } \\
\text { mesenchyme, odontoblasts, palate, tongue (Aberg et al., } \\
\text { 1997, Bennett et al., 1995, Francis-West et al., 1994, Lu et } \\
\text { al., 2000, Nie, 2005a, Nie, 2005c, Yamashiro et al., 2003) }\end{array}$ & Die around E7.5 to E10.5, defects in cardiac development (Zhang and Bradley, 1996) \\
\hline Bmp4 & $\begin{array}{l}\text { Cranial neural crest, early facial primordia, skeletons, } \\
\text { dental epithelia and mesenchyme, preodontoblasts, } \\
\text { palate, tongue (Aberg et al., 1997, Bennett et al., 1995, } \\
\text { Francis-West et al., 1994, Gong and Guo, 2003, Lu et al., } \\
2000 \text {, Nie, 2005a, Nie, 2005c, Vainio et al., 1993, } \\
\text { Yamashiro et al., 2003) }\end{array}$ & $\begin{array}{l}\text { Die between E6.5 to E9.5, little or no mesoderm formation (Winnier et al., 1995) } \\
\text { Conditioned knockout in craniofacial region: cleft lips (Liu et al., 2005) } \\
\text { Related disorder: fibrodysplasia ossificans pregressiva (OMIM, 135100) }\end{array}$ \\
\hline Bmp3 (osteogenin) & $\begin{array}{l}\text { Osteoblast, cementoblasts and follicles of tooth, tongue, } \\
\text { palate (Aberg et al., 1997, Nie, 2005a, Nie, 2005c, } \\
\text { Yamashiro et al., 2003) }\end{array}$ & High bone density (Daluiski et al., 2001) \\
\hline Bmp5 & $\begin{array}{l}\text { Skeleton, ear, epithelial ameloblasts, palate, tougue } \\
\text { (Aberg et al., 1997, King et al., 1994, Lu et al., 2000, Nie, } \\
\text { 2005a) }\end{array}$ & $\begin{array}{l}\text { Sponteneous mutation: viable, short ears with skeleton defects (King et al., 1994, Kingsley et al., 1992) } \\
\text { Related disorder: short ear phenotype in mice }\end{array}$ \\
\hline Bmp6 & $\begin{array}{l}\text { Hypertrophic chondrocytes, osteoblasts, tooth pulp, } \\
\text { tongue (Eames and Helms, 2004, Nakashima et al., 1998, } \\
\text { Nie, 2005a) }\end{array}$ & Viable and fertile, mild defects in the sternum (Solloway et al., 1998) \\
\hline $\begin{array}{l}\text { Bmp7 (Osteogenic } \\
\text { protein 1, OP1) }\end{array}$ & $\begin{array}{l}\text { Early orofacial epithelial, skeleton, eyes, notochord, early } \\
\text { tooth (Aberg et al., 1997, Barlow and Francis-West, 1997, } \\
\text { Dudley and Robertson, 1997) }\end{array}$ & $\begin{array}{l}\text { Die around birth, deformities in kidney and eyes, a hole in the basisphenoid bone and xyphoid cartilage } \\
\text { (Dudley et al., 1995, Jena et al., 1997) } \\
\text { Bmp5/7 double knockout mice: die at E10.5, reduced size of branchial arches (Solloway and Robertson, } \\
\text { 1999) }\end{array}$ \\
\hline Bmp8 (OP2) & $\begin{array}{l}\text { Early embryogenesis, skeleton, tooth pulp (DiLeone et al., } \\
\text { 1997, Nakashima et al., 1998, Ozkaynak et al., 1992) }\end{array}$ & Germ cell degeneration (Zhao et al., 1998) \\
\hline Gdf1 & $\begin{array}{l}\text { Ventral neural tube, midbrain, paraxial mesoderm (Rankin } \\
\text { et al., 2000, Wall et al., 2000) }\end{array}$ & Defects in left-right axis formation (Rankin et al., 2000) \\
\hline Gdf5 (CDMP1) & $\begin{array}{l}\text { Joint, tooth attachment apparatus and pulp (Nakashima et } \\
\text { al., 1998, Sena et al., 2003, Settle et al., 2003) }\end{array}$ & $\begin{array}{l}\text { Naturally occurred mutation in mice: brachypod syndrome, (Storm et al., 1994, Storm and Kingsley, 1996) } \\
\text { Related disorders: loss function mutation associated with Brachychod in mice, chondrodysplasia Grebe } \\
\text { type (OMIM, 200700) and Hunter-Thompson type of acromesomelic dysplasia (OMIM, 201250) in human. } \\
\text { Haploinsufficiency mutation associated with brachydactyly type C (OMIM, 113100) }\end{array}$ \\
\hline Gdf6 (Bmp13/CDMP2) & $\begin{array}{l}\text { Coronal suture of the calvaria, middle ear cartilage, tooth } \\
\text { attachment apparatus and pulp (Nakashima et al., 1998, } \\
\text { Sena et al., 2003, Settle et al., 2003) }\end{array}$ & $\begin{array}{l}\text { Defects in middle ear cartilage, absence of coronal suture (Settle et al., 2003) } \\
\text { Related disorder: possibly related to carniosynostosis }\end{array}$ \\
\hline Gdf7 (Bmp12/CDMP3) & $\begin{array}{l}\text { Roof plate of the brain, tooth attachment apparatus (Lee et } \\
\text { al., 1998, Nakashima et al., 1998, Sena et al., 2003, Settle } \\
\text { et al., 2001) }\end{array}$ & In mutant mice, the D1A neurons is eliminated (Lee et al., 1998) \\
\hline Gdf8 (myostatin) & Muscles (McPherron et al., 1997) & $\begin{array}{l}\text { Large size and increased muscle mass (Byron et al., 2004, McPherron et al., 1997) } \\
\text { Related disorders: gross muscle hypertrophy (Schuelke et al., 2004) }\end{array}$ \\
\hline Gdf10 (Bmp3b) & $\begin{array}{l}\text { Basicranium, nasal cavity, inner ear, palate, brain (Zhao et } \\
\text { al., 1999) }\end{array}$ & No obvious abnormity (Zhao et al., 1999) \\
\hline Gdf11 (Bmp11) & $\begin{array}{l}\text { Branchial arch, nasal epithelium, retina, palate, } \\
\text { odontoblasts, brain (McPherron et al., 1999, Nakashima et } \\
\text { al., 1999) }\end{array}$ & $\begin{array}{l}\text { Die shortly after birth, renal defect, anteriorly directed homeotic transformation of axis skeleton, palate } \\
\text { anomaly (McPherron et al., 1999) }\end{array}$ \\
\hline Alk2 & $\begin{array}{l}\text { Facial primordia, pharyngeal branches (Dudas et al., } \\
\text { 2004) }\end{array}$ & $\begin{array}{l}\text { Die before E9.5 (Gu et al., 1999, Mishina et al., 1999) } \\
\text { Conditioned knockout in craniofacial region: survived, short head, hypotrophic and deformed mandible, } \\
\text { incomplete zygomatic arch, Meckel cartilage abnormity, cleft palate (Dudas et al., 2004) }\end{array}$ \\
\hline Bmprla (Alk3) & $\begin{array}{l}\text { Broadly expressed in craniofacial region (Dewulf et al., } \\
\text { 1995) }\end{array}$ & $\begin{array}{l}\text { Die around E9, no mesoderm formation (Mishina et al., 1995) } \\
\text { Conditioned knockout in craniofacial region: survived, bilateral cleft palate, tooth arrestment (Liu et al., } \\
2005) \\
\text { Related disorder: Juvenile intestinal polypopsis (OMIM, 174900) }\end{array}$ \\
\hline Bmprlb (Alk6) & $\begin{array}{l}\text { Skeleton, premuscle masses, blood vessels, central } \\
\text { nervous system, developing ear and eye, and epithelium } \\
\text { (Dewulf et al., 1995) }\end{array}$ & Viable, appendicular skeleton defects (Yi et al., 2000) \\
\hline Bmprll & Ubiquitously in early embryo (Beppu et al., 2000) & $\begin{array}{l}\text { Die before E9.5, fail to form organized structure and mesoderm (Beppu et al., 2000) } \\
\text { Related disorder: Pulmonary hypertension (OMIM, 178600) }\end{array}$ \\
\hline
\end{tabular}


development, fails to be upregulated at a crucial developmental stage and results in cleft lips. Those authors demonstrated that the Bmp4/Bmprla pathway is critical for the lip development (Liu et al., 2005). This model also implies that Bmp4 is a possible candidate gene related to isolated cleft lips. Normal orofacial union of the other parts in this model suggests distinct mechanisms of the orofacial union along the anterior-posterior axis. Expression of Bmp4 is shown in the early developing facial primordia in Fig. 1.

Knockout of $B m p 7$, the other Bmpmember expressed in early facial epithelia, shows no obvious defects in facial structures except for the eyes (Dudley et al., 1995, Luo et al., 1995, Solloway and Robertson, 1999), while Bmp5/Bmp7double knockout mice show early embryo death and deficiency of facial primordia development, suggesting functional redundancies among the $60 \mathrm{~A}$ subgroup of the Bmpgene family. Functional redundancy is likely an evolutionary strategy for some of the crucial genes.

\section{BMP signalling in craniofacial skeletogenesis}

The BMP signal is critical for skeletogenesis throughout the body, regulating chondrogenesis and osteogenesis at multiple stages. The molecular mechanism of BMPs in these processes has been extensively investigated, producing a large body of literatures in the past decade. BMP signalling is involved in determination, migration, condensation, proliferation, differentiation and apoptosis of skeletal cells. In those processes, the Bmp signalling pathway interacts with Fgf, Hedgehog and Wnt signalling pathways and regulates the expression of several critical transcription factors such as Sox9, Cbfa1 and Msx (Karsenty, 1999, Karsenty, 2003, Minina et al., 2002, Minina et al., 2001, Naski etal., 1998). In the Bmp gene family, Bmp2, -4, -7, -3, -5 and

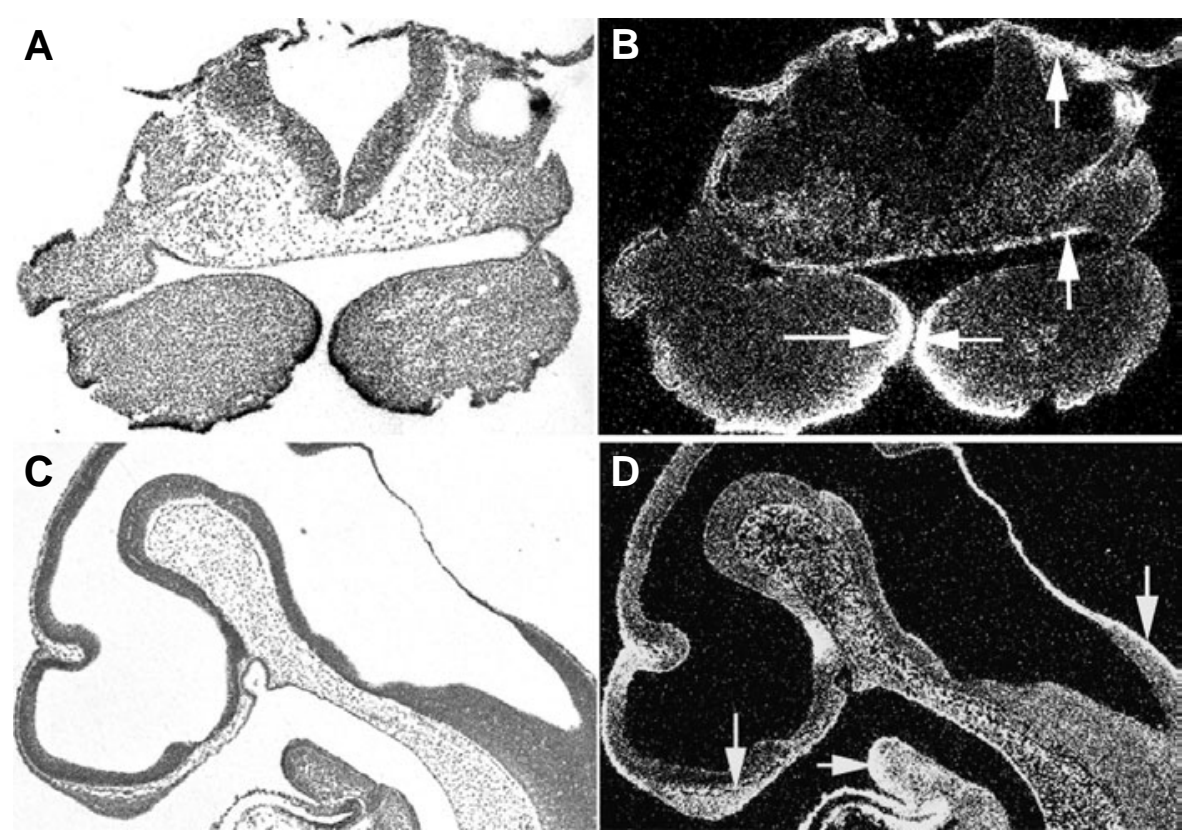

Fig. 1. Bmp4 expression in the developing mouse head at embryo day 10 (E10) localized by radioactive in situ hybridization. At E10, Bmp4 is intensely expressed in the epithelia of the first branchial arches, stomodeum and ectoderm of cranial neural crest (arrows). (A,C) bright field section; (B,D) dark field section.
Gdf5 are critical in skeletogenesis. The vast majority of studies on skeletogenesis have been carried out using appendicular bones as a model system. A number of reviews concerning the roles of Bmps in skeletogenesis are available (Chen et al., 2004, Karsenty, 1999, Karsenty, 2003, Yoon and Lyons, 2004). However, craniofacial skeletogenesis is not identical to that of appendicular bones (Eames and Helms, 2004, Helms and Schneider, 2003). This part of the review focuses on the roles of Bmp signalling in craniofacial skeletogenesis.

Bones in craniofacial area are mostly derived from the CNCCs and formed through intramembranous ossification, in which process mesenchymal cells directly condense and differentiate into osteoblasts without any cartilage model. One exception is the basicranium, which is formed through endochondral ossification, in which process bone formation is guided by a cartilage template similar to that of the appendicular bones. The vertebrate basicranium evolutes from the ancient floor of the brain, with evolutionary new elements derived from the CNCCs in its anterior part (Nie, 2005b). During calvaria development, open fibrous sutures among intramembranous bones are formed as growth centres. In the endochondral basicranium, cartilaginous growth centres that are morphologically and functionally similar to the growth plates, termed synchondroses, are developed for this function. The facial bones are connected by relatively narrow fibrous sutures except for the mandible, which is a relatively independent and movable skeleton in the craniofacial area. In the mandible, secondary cartilage structures, the mandible condyles, are developed as growth centres for the posterior part of the mandible. Although the condyle cartilage basically contributes to mandible growth through endochondral bone formation as that of growth plate, it also displays unique features in development and regulation. The condyle cartilage differs to the primary cartilage in embryonic origin, histological organization, growth mode and regulation (Delatte et al., 2004, Shibata et al., 1996).

BMP signalling is conserved in craniofacial skeletons regulating both the endochondral and intramembranous bone formation (Fig. 2). It is crucial for the formation of skeletogenic precursor cells in the neural crest and their migration to the defined destinations (Kanzler et al., 2000). Bmps are highly expressed in the migrating CNCCs and later in the early stage of cartilages and bones. Overexpression of Bmp or application of Bmp proteins changes the skeletal patterning process, resulting in altered size and morphology of the skeleton in both the face and limb (Barlow and Francis-West, 1997, Duprez et al., 1996a). Moreover, deficiency of Bmp signalling in mouse cranial neural crest shows multiple defects in craniofacial skeletons (Dudas etal., 2004). These data indicate a patterning role for craniofacial skeletogenesis.

After early development, Bmps maintain their expression in the skeletons and skeletal growth centres and play an important 
role in regulating the activities of the growth centres. The cranial sutures are critical growth sites for the calvarias. Premature fusion of these sutures leads to a pathologic condition, known as craniosynostosis. The Bmp signal is an important player in regulating the sutural morphogenesis and function (Holleville et al., 2003, Kim et al., 1998). Both Bmp2 and Bmp4 are present in the osteogenic fronts of cranial sutures (Kim et al., 1998). Application of Bmp4 protein increases the tissue volume in the suture and induces the expression of Msx genes (Kim et al., 1998), which is also associated with craniosynostosis in mutated conditions. In avian suture, Bmp signalling induces and upregulates the expression of homeobox gene DIx5 (Holleville et al., 2003), a critical factor for development of craniofacial skeletons (Acampora et al., 1999, Depew et al., 1999). Gdf6 is another important signal in suture regulation. It was found in the coronal suture, whereas other members of this subgroup, Gdf5 and Gdf7, were not detected (Settle et al., 2003). In Gdf6 mutant mice, the coronal suture of the skull, normally joining the frontal and parietal bones, is consistently missing (Settle et al., 2003). This role of Gdf6 proposes it as a candidate
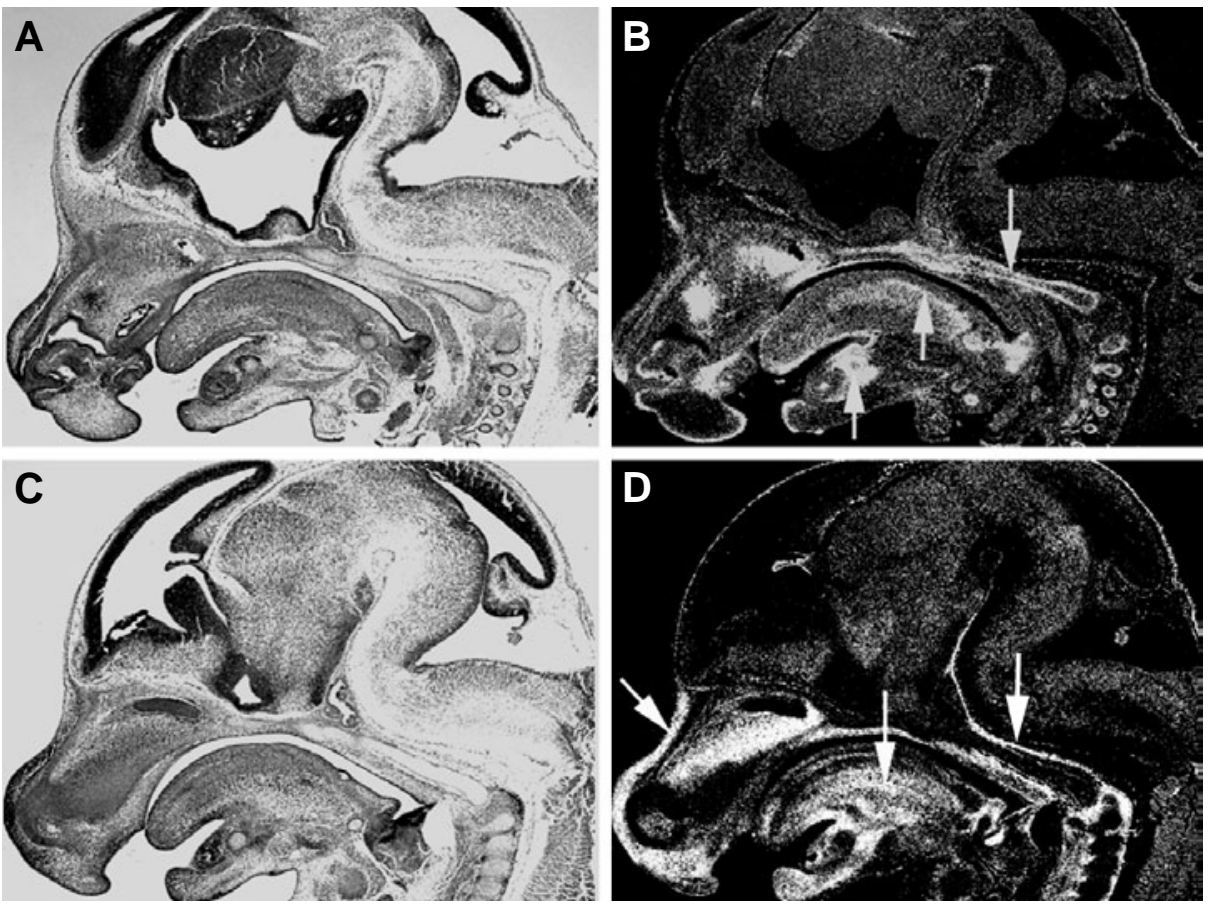

Fig. 2. Expression of Bmp2 and Bmp4 in the developing mouse head at E13. Bmp2 is seen in the chondrocranium, myogenic mesenchyme of the tongue and nasal and mandibular cartilages $(\mathbf{A}, \mathbf{B})$. Bmp4 is widespread in the perichondria of the chondrocranium, nasal cartilage,tongue and mesenchyme of the facial prominences (C,D). Arrows indicate expression domains. gene of craniosynostosis. Bmpr1b is important for skeletogenesis. In the craniofacial region it is highly present in both developing and adult skeletal elements. Transgenic expression of truncated Bmpr1b in mouse osteoblasts using the type I collagen promoter leads to delayed ossification in the calvarias (Zhao et al., 2002).

During basicranium development, Bmp2 to -6 displays a spatiotemporal expression that largely conforms to that of other endochondral skeletons (Nie et al., unpublished data). The effect of Bmp signalling on synchondrosis of basicranium was specifically analyzed using a serum-free organ culture system (Shum et al., 2003). Bmp protein stimulates cartilage growth, matrix deposition and chondrocyte proliferation in a dose dependent manner. The regulation of synchondrosis by Bmp signalling appears

\section{TABLE 2}

\section{SOME ADDITIONAL MEMBERS OF THE BMP FAMILY: EXPRESSION PROFILES AND RELATED DISORDERS}

\begin{tabular}{|c|c|}
\hline & Expression profile \\
\hline Bmp9 (Gdf2) & Central nervous system, Liver (Lopez-Coviella et al., 2000, Miller et al., 2000) \\
\hline Bmp10 & High in heart, lower in lung and liver (Neuhaus et al., 1999) \\
\hline \multirow[t]{2}{*}{ Bmp15 } & Ovary (Dube et al., 1998) \\
\hline & Related disorder: Ovary dygenesis 2 (OMIM, 300510) \\
\hline \multirow[t]{2}{*}{ Gdfg } & Ovary (Dube et al., 1998, Teixeira Filho et al., 2002) \\
\hline & Related disorder: Polycystic ovary syndrome (Teixeira Filho et al., 2002) \\
\hline Gdf 3 & Embryonal carcinoam cell line (Caricasole et al., 1998) \\
\hline \multirow[t]{2}{*}{ Nodal } & Early embryo, involved in establishing proximal-distal polarity (Kishigami and \\
\hline & Mishina, 2005) \\
\hline lefty & $\begin{array}{l}\text { Notochord, presumptive floor plate, involved in left-right patterning (Kishigami } \\
\text { and Mishina, 2005) }\end{array}$ \\
\hline
\end{tabular}

largely similar or identical to that of its morphologic analogue - the growth plate.

BMP signalling is also important for mandible development. Inactivation of Alk2 in mouse neural crest results in a remarkable hypotrophic mandible (Dudas et al., 2004). In such mice, the anterior cartilage derived from the distal extremity of the Meckel's cartilage is absent; subsequently the mental symphysis, a critical growth site for anterior part of mandible, is not formed resulting in persistently separated mandible bones (Dudas et al., 2004). In line with this, simultaneous abrogation of two Alk2 ligands, Bmp5 and Bmp7, leads to defects in proliferation and maintenance of branchial arch cells (Solloway and Robertson, 1999). Bmp/Msx signal loop is critical for alveolar bone formation of the mandible. In Msx1/- mice, tooth development is arrested at the bud stage and associated with this is an absence of periodontal bone- the alveolar process. On the other hand, ectopic expression of Bmp4 driven by the mouse Msx1 promoter to the Msx $1^{-/-}$dental mesenchyme not only partially restores tooth development, but also rescues alveolar bone formation (Zhao et al., 2000). It was later demonstrated that Bmp4 mediates the function of Msx1 in controlling the development of the alveolar bone by regulating the expression of Dlx5 and Cbfa1 (Zhang et al., 2003). The mechanism of temporomandibular joints (TMJ) development is poorly understood. Bmp2 and Bmp4 have been implied a role in determining the site of the TMJ by repressing Bapx1 (Wilson and Tucker, 2004). Gdf5, -6 and -7 subgroup is required for synovial joint formation (Settle et al., 2003, Storm and Kingsley, 1996), but their roles in the development of TMJ remain to be specifically defined. How the Bmp signalling regulates the development of 


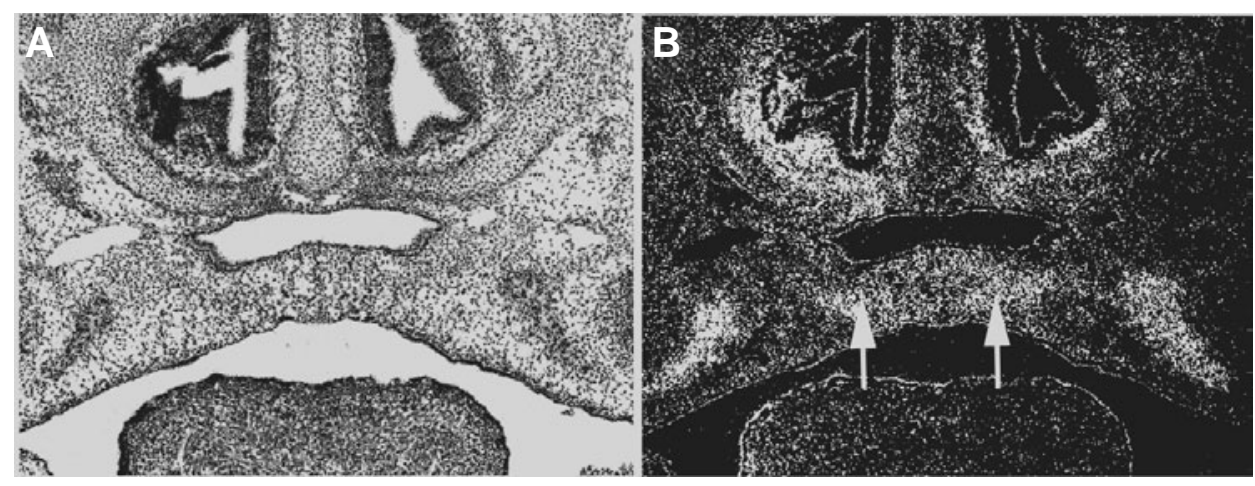

Fig. 3. Expression of Bmp2 in palatogenesis. Bmp2 is highly expressed in the palatal mesenchyme adjacent to the midline during palatal fusion (arrows). (A) Bright field section; (B) Dark field image.
Bmp4 and Bmp5 are expressed in mouse palate in both the epithelia and mesenchyme prior to, during and after palatal shelf fusion (Lu et al., 2000, Nie, 2005c, Zhang et al., 2002). The expression is highly dynamic during palatogenesis and is differently regulated along the anterior-posterior axis (Nie, 2005c). The importance of Bmp signalling in palatogenesis is implied by a mice model of cleft palate. In such mice, cleft palate induced by retinoic acid is associated with decreased expression of Bmp2, -4 and -5 (Lu et al., 2000). More convincing evidence is the secondary cartilage of the mandible, the condyles, also remains to be analyzed.

The BMP family is also found to be a heterogonous group in functions. BMP3 and BMP3b (GDF10) together represent a unique subgroup of this family. The role of BMP3 in skeletogenesis is controversial, owning to contradictory results (Bahamonde and Lyons, 2001, Han et al., 2002). Now evidence is stronger in supporting an inhibitory role for bone formation. Bmp3 knockout mice have increased bone density that are twice as much trabecular bone as wild type (Bahamonde and Lyons, 2001, Daluiski et al., 2001). Bmp3 antagonized Bmp2induced osteoblastic differentiation in vitro by a receptor independent way (Bahamonde and Lyons, 2001). Bmp3b has a similar antagonistic activity against Bmp2, but is differentially regulated (Daluiski et al., 2001).

The inductive and regulatory roles of BMP signalling in skeletogenesis provide an important approach in skeletal tissue regeneration and engineering. Application of BMP proteins, BMP-induced or BMP-expressing stem cells, or BMP gene transfer could greatly facilitate the regeneration process of bone and cartilage (Chang et al., 2004, Lieberman et al., 1999, Lieberman et al., 1998, Suzuki et al., 2002). Skeletal tissue can even be produced in vitro by combination of stem cells with suitable matrix and inductive molecules such as Bmps. Breakthroughs in this field will undoubtedly provide a powerful armoury for craniofacial skeletal repair.

\section{BMP signalling in palatogenesis}

The development of palate is a complex process. Union of the primary palate of frontonasal process and paired lateral maxillary palatal shelves, which form the secondary palate, forms the mammalian palate. Formation of mammalian secondary palate is a multi-step process that includes mesenchymal cell proliferation, palatal shelf outgrowth, elevation, fusion and eventually disappearance of the midline epithelial seam. Disturbance of any events may lead to clefts in the palate. The most common mechanism of cleft is due to deficiency of mesenchymal proliferation or failure of epithelial fusion. Cleft palates with or without cleft lips occur either as isolated cases or simultaneous with human syndromes. Even though syndromic and isolated cleft palates are different in mechanisms, both types show high genetic background.

The Bmp signal is essential for palatogenesis. Bmp2, Bmp3, provided by studies of transgenic mice models with inactivation of Alk2 or Bmprla specifically in the neural crest or facial primordia, both of which consistently show oro-facial cleft (Dudas et al., 2004, Liu et al., 2005). This also implies that Bmp signalling mediated by Alk2 and Bmprla plays non-redundant roles in palatogenesis.

While inactivation of Bmprla in the facial primordia leads to palatal cleft, removal of Bmprla from the epithelia along does not show obvious affliction on palatogenesis in mice (Andl et al., 2004). The secondary palate of Bmprla ${ }^{\mathrm{fp}-/-}$ mice is associated with diminished proliferation and elevated apoptosis and the are placed together in culture, suggesting that the cleft in Bmprla deficiency mice is due to lack of mesenchymal proliferation rather than failure of epithelial fusion (Liu et al., 2005). In line with this, high expression of Bmp2 was observed in the mesenchyme adjacent to midline during palatal fusion (Fig. 3), whereas epithelial signalling mediated by Bmp4 and Bmp7 is either unessential or functional redundant with others as implicated by conditioned knockout models (Dudley et al., 1995, Liu et al., 2005, Nie, 2005c). Other members of the Bmp family do not appear crucial for palatogenesis, implicated by functional studies (Tables 1 and 2). Therefore, it is logical to speculate that Bmp2-mediated mesenchymal proliferation is a key event in palatogenesis. The Bmp signal has been proposed to be within the Msx1-induced signalling pathway in palatogenesis. Msx1 deletion leads to a complete cleft in the secondary palate in mice (Satokata and Maas, 1994), whereas transgenic expression of Bmp signal driven by Msx1 promoter rescues the clefts (Zhang et al., 2002), suggesting that the Bmp signal is downstream of Msx1 in palatogenesis. Recently, Bmp11 (Gdf11) has been implicated a role in palatogenesis by transgenic approach (McPherron et al., 1999). Unfortunately, detailed phenotype analysis is not available to date. Regarding to epithelial fusion, Tgf- $\beta 3$ has been shown to be a pivotal factor (Gato et al., 2002).

Those data also indicates differential requirement of $\mathrm{Bmp}$ signalling in palate and lip formation and thus potential different mechanisms underling these processes. For instance, Bmp4 are critical for the fusion process of lip development, whereas in palatogenesis Bmp signalling is implicated to be a signal for mesenchymal proliferation (Liu et al., 2005). The development and fusion of palate is also relatively a late event in embryogenesis and is critically influenced by development of related structures. All these aspects make palatogenesis a very fragile palatal shelves of the mutants are competent to fuse when they 
process that is easily affected by genetic and environmental factors.

\section{BMP signalling in craniofacial skeletal muscle devel- opment}

The Bmp signal is not essential for the early initiation of myogenesis. On the contrary, repression of the Bmp signal is required for early development of craniofacial muscles (Tzahor et al., 2003). During muscular regeneration, the Bmp signal is also absent (Zhao and Hoffman, 2004). An inhibitory role in myogenesis is implicated for Bmp signalling by many studies (Duprez et al., 1996b, Huang et al., 2001, Inada et al., 1996, Musgrave et al., 2001, Tzahor et al., 2003). Of note, the myostatin (Gdf8) was identified as a key regulator in skeletal muscle development and growth (McPherron et al., 1997). Gdf8 is specifically expressed in developing and adult skeletal muscles. Gdf8 null mutant mice are significantly larger than wild type mice and show a dramatic and widespread increase in skeletal muscle mass (McPherron et al., 1997). Significantly, heterozygous mice are also affected, although in a less degree, suggesting that the effect of myostatin is dose dependent (McPherron et al., 1997).

The craniofacial muscles are mostly derived from mesoderm and formed within a surrounding environment of neural-crestderived elements (Noden, 1983, Noden, 1988). Their development is characterized of early expression of myogenic regulatory factors (MRFs) and thus early maturation. Bmp signalling is present during craniofacial muscle development. The tongue is a good model for studying craniofacial myogenesis, for it is basically a muscle organ. Many Bmps have been localized in muscles of developing tongue (Bennett et al., 1995, Huang et al., 2001, Nie, 2005a). Application of Noggin, an antagonists of Bmps, to the avian tongue results in thickening of the tongue (Huang et al., 2001), conforming to the negative role of Bmp signalling in muscle development in general. In myostatin-deficient mice, the temporalis mass becomes significantly large (Byron et al., 2004). Therefore, Bmp signalling plays a role in controlling the pace of myogenic proliferation and differentiation of craniofacial muscles.

BMP4 mutation is associated with fibrodysplasia ossificans progressiva (FOP, OMIM no.135100), characterized by progressive postnatal heterotopic ossification in muscles. The fibroproliferative lesions evolve through endochondral ossification into a mature laminar bone with marrow elements. Trans-
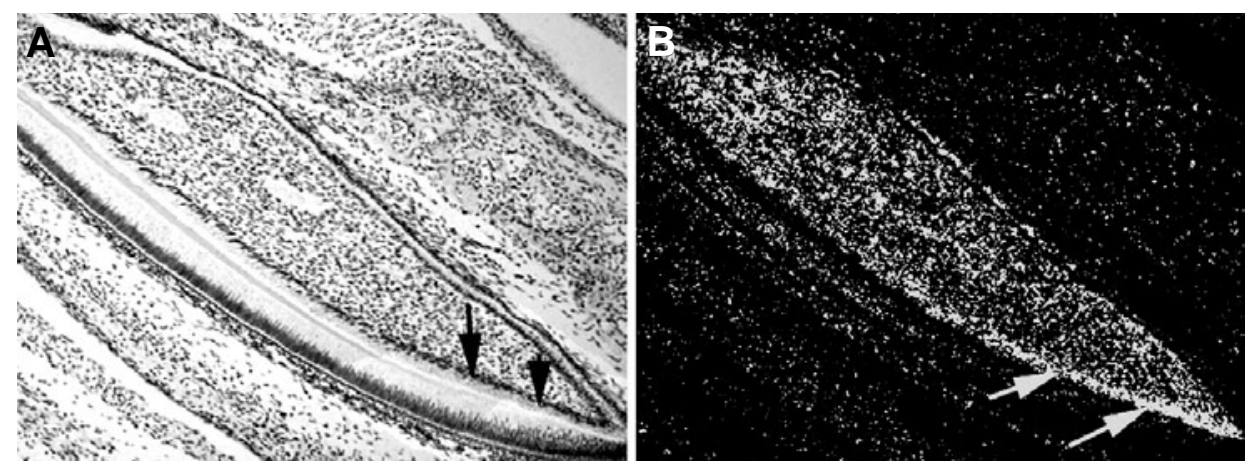

Fig. 4. Bmp2 expression in the mouse incisor in the lower jaw at newborn stage. Intense expression is seen in odontoblasts near the tooth root. Arrows indicate expression domains. (A) Bright field image; (B) dark field image. genic mice overexpressing Bmp4 develop a similar phenotype like FOP (Kan et al., 2004). In a child with gross muscle hypertrophy, loss function mutation of myostatin gene was detected (Schuelke et al., 2004), suggesting the inactivation of myostatin has similar effects in mice and human.

\section{BMP signalling in tooth development}

Tooth morphogenesis initiates from thickening of stomodeal epithelium. This dental lamina gives rise to epithelium buds for further development. Thereafter early tooth bud coupled with underlining mesenchyme undergoes successive morphological changes known as cap stage and bell stage. The Bmp signal is also a fundamental regulator of tooth development, as evidenced by the arrestment of tooth development in Bmpr1a deficient mice (Andl et al., 2004, Liu et al., 2005). At the early tooth initiation stage, Bmp4, Bmp2 and Bmp7, expressed in dental epithelia, play an important role in epithelial-mesenchymal interactions in inducing tooth formation (Aberg et al., 1997, Vainio et al., 1993). During the bud to cap transitional stage, Bmp4 induces the expression of Msx1 and Msx2 in the mesenchyme. The latter signalling further induces Bmp4 expression in the mesenchyme. Ectopic Bmp4 expression driven by mouse Msx1 promoter partially rescues tooth development in the Msx1-deficient mice (Zhao et al., 2000).

Therefore, Bmp/Msx signal loop mediates reciprocal interactions between the epithelium and mesenchyme during tooth initiation and crown morphogenesis.

In the developing mouse tooth germ Bmp4 regulates the expression of another critical patterning gene, the Shh (Zhang et al., 2000). Inhibition of Bmp4 activity by Noggin resulted in repression of Shh and Bmp2 in wild-type dental epithelium (Zhang et al., 2000), while ectopic expression of human BMP4 to the dental mesenchyme driven by mouse Msx1 promoter restored Shh expression in the Msx1 mutant dental epithelium (Zhang et al., 2000, Zhao et al., 2000). In subsequent development, Bmp4 is expressed in preodontoblasts and its expression is sharply downregulated after their differentiation, whereas Bmp2 expression is upregulated during the terminal differentiation of odontoblasts (Nakashima, 1994, Nakashima and Reddi, 2003, Yamashiro et al., 2003). These data suggests that the Bmp signal is inductive to odontoblastic differentiation. In Fig. 4, mRNA expression of $\mathrm{Bmp2}$ in the developing mouse incisor is shown. Additionally, Bmp3 was localized in cementoblasts and dental follicles (Yamashiro et al., 2003); Bm6, Bmp8 and Gdf7 were identified in dental pulp (Nakashima et al., 1998); Gdf11 was observed in the terminally differentiated odontoblasts (Nakashima etal., 1999); while Gdf5, -6 and -7 were detected in the periodontium (Sena et al., 2003).

The role of inducing odontoblastic differentiation provides potential application for dental tissue engineering and regeneration. Recently, dental pulp stem cells was induced into odontoblasts in a culture system by Bmp2, as indicated by marker genes like dentin sialophosphoproteinn (lohara et al., 2004). Based on the in vitro experiments, Bmp-treated pellet culture 
of pulp stem cells transplanted to amputated pulp markedly stimulated dentin formation (lohara et al., 2004). These advances provide potential clinical use of stem cells in the regeneration of tooth tissue or even replacement of missing tooth with engineered tooth primordia.

\section{BMP signalling involved in apoptosis in craniofacial development}

Bmp signalling is involved in apoptosis in developing limb (Macias etal., 1997, Omi etal., 2000, Yokouchi etal., 1996). Msx2 was further demonstrated to be the mediator of Bmp-induced apoptosis in a in vitro system (Marazzi et al., 1997). In the developing head, Bmp signalling is also associated with apoptosis during development of the cranial neural crest, facial primordia and eye (Barlow and Francis-West, 1997, Graham et al., 1994, Guha et al., 2002). In chicken cranial neural crest, Bmp4 induces apoptosis in rhombomeres (r) 3 and $r 5$ through upregulating the expression of Msx2 (Graham et al., 1994). Addition of recombinant BMP4 protein to explant cultures of $\mathrm{r} 3$ or $\mathrm{r} 5$, which produce neural crest when isolated from their neighbouring rhombomeres, upregulates Msx2 expression and reinstates apoptosis in the neural crest population (Graham et al., 1994). Further more, overexpression of Msx2 along the cephalic neural tube also results in increased apoptosis (Takahashi et al., 1998). Apoptosis in the neural crest is suggested as a mechanism of eliminating those cells that are not necessary for differentiation and results in the sculpting of discrete migratory streams of neural crest in chicken.

In contrast to chicken, mice do not show the rhombomerespecific cell death. Although consistent and reproducible cell death is observed in the hindbrain, there is no specific pattern that could be attributed to either odd or even rhombomeres (Kulesa et al., 2004). Mouse Bmp4 is not expressed in the $r 3$ and $r 5$ and is actually absent from the dorsal neural tube (Kulesa et al., 2004). Moreover, Msx2 is expressed uniformly in the dorsal edges of the neural tube along the entire anterior-posterior axis during the period of neural crest formation and migration, differing markedly from the patterns of the chicken homologue (Kulesa et al., 2004). Therefore, Bmp4/Msx2 mediated apoptosis of neural crest cells in odd-numbered rhombomeres is not responsible for patterning the pathways of the neural crest migration in mice. This also holds true in zebrafish and Xenopus. These data suggest that apoptosis in $\mathrm{r} 3$ and $\mathrm{r} 5$ of chicken is an evolutionary species-specific feature.

Bmp signalling is also associated with apoptosis in early facial development. The expression of Bmp2 and Bmp4 overlaps with domains of cell death in the frontonasal mass and regions of union between primordia (Barlow and Francis-West, 1997). Moreover, exogenous Bmp protein induces cell death in facial primordia (Barlow and Francis-West, 1997). Of note, in Bmp5/Bmp7 double mutant mice apoptosis pattern in the branchial arch and dorsal midline is altered (Solloway and Robertson, 1999). Collectively, these results support an apoptotic role of Bmp signalling in some processes of craniofacial development.

\section{Concluding remarks}

In summary, functions of BMP signaling have been under revealing in a variety of craniofacial structures. The BMP signal is conserved in many developmental processes, but mediates distinct functions in different tissues and stages. Its specific roles and mechanisms in the development of craniofacial elements clearly need further elucidation. Crosstalk between the BMP and other signalling pathways remains to be clarified. Particularly the downstream factors of the BMP signal are not completely identified in many processes. These factors are usually site-specific. Therefore, unraveling the BMP signalling pathway within the genetic cascade of a certain developmental process is important for understanding of the overall mechanism. The developmental roles of BMPs also provide an important approach in tissue engineer and regeneration. Therefore, the BMP signalling pathway will undoubtedly continue to attract attention in future studies.

\section{Summary}

The BMP signalling pathway is conserved throughout evolution and essential for mammalian embryonic and postnatal development and growth. In the vertebrate head, this signal is involved in the development of a variety of structures and shows divergent roles. During early head development, BMP signalling participates in the induction, formation, determination and migration of the cranial neural crest cells, which give rise to most of the craniofacial structures. Subsequently, it is also important for patterning and formation of facial primordia. During craniofacial skeletogenesis, BMP signalling is an early inductive signal required for committed cell migration, condensation, proliferation and differentiation. Thereafter, BMP signalling maintains regulatory roles in skeletons and skeletal growth centres. For myogenesis, BMP signalling is a negative regulator. Importantly, myostatin has been identified as a key mediator in this process. During palatogenesis, the crucial role of BMP signalling is demonstrated by mouse models with $A / k 2$ or Alk3 (BMP type I receptors) deletion from the neural crest or craniofacial region, in which cleft palate is one of the major anomalies. BMP signalling is also an important participant for tooth development, regulating early tooth morphogenesis and subsequent odontoblast differentiation. In this review these aspects are discussed in detail with a focus on recent advances.

\section{References}

ABERG, T., WOZNEY, J. and THESLEFF, I. (1997). Expression patterns of bone morphogenetic proteins (bmps) in the developing mouse tooth suggest roles in morphogenesis and cell differentiation. Dev Dyn 210: 383-96.

ACAMPORA, D., MERLO, G.R., PALEARI, L., ZEREGA, B., POSTIGLIONE, M.P., MANTERO, S., BOBER, E., BARBIERI, O., SIMEONE, A. and LEVI, G. (1999). Craniofacial, vestibular and bone defects in mice lacking the distal-less-related gene dlx5. Development 126: 3795-809.

ANDL, T., AHN, K., KAIRO, A., CHU, E.Y., WINE-LEE, L., REDDY, S.T., CROFT, N.J., CEBRA-THOMAS, J.A., METZGER, D., CHAMBON, P. et al. (2004). Epithelial bmpr1a regulates differentiation and proliferation in postnatal hair follicles and is essential for tooth development. Development 131: 2257-68.

BAHAMONDE, M.E. and LYONS, K.M. (2001). Bmp3: To be or not to be a bmp. $J$ Bone Joint Surg Am 83-A Suppl 1: S56-62.

BARLOW, A.J. and FRANCIS-WEST, P.H. (1997). Ectopic application of recombinant bmp-2 and bmp-4 can change patterning of developing chick facial primordia. Development 124: 391-8.

BENNETT, J.H., HUNT, P. and THOROGOOD, P. (1995). Bone morphogenetic protein-2 and -4 expression during murine orofacial development. Arch OralBiol 40: 847-54. 
BEPPU, H., KAWABATA, M., HAMAMOTO, T., CHYTIL, A., MINOWA, O., NODA, T. and MIYAZONO, K. (2000). Bmp type ii receptor is required for gastrulation and early development of mouse embryos. Dev Bio/221: 249-58.

BYRON, C.D., BORKE, J., YU, J., PASHLEY, D., WINGARD, C.J. and HAMRICK, M. (2004). Effects of increased muscle mass on mouse sagittal suture morphology and mechanics. Anat Rec A Discov Mol Cell Evol Biol279: 676-84.

CARICASOLE, A.A., VAN SCHAIK, R.H., ZEINSTRA, L.M., WIERIKX, C.D., VAN GURP, R.J., VAN DEN POL, M., LOOIJENGA, L.H., OOSTERHUIS, J.W. PERA, M.F., WARD, A. et al. (1998). Human growth-differentiation factor 3 (hgdf3): Developmental regulation in human teratocarcinoma cell lines and expression in primary testicular germ cell tumours. Oncogene 16: 95-103.

CHANG, S.C., CHUANG, H., CHEN, Y.R., YANG, L.C., CHEN, J.K., MARDINI, S., CHUNG, H.Y., LU, Y.L., MA, W.C., LOU, J. et al. (2004). Cranial repair using bmp-2 gene engineered bone marrow stromal cells. J Surg Res 119: 85-91.

CHEN, D., ZHAO, M., HARRIS, S.E. and MI, Z. (2004). Signal transduction and biological functions of bone morphogenetic proteins. Front Biosci9: 349-58.

DALUISKI, A., ENGSTRAND, T., BAHAMONDE, M.E., GAMER, L.W., AGIUS, E., STEVENSON, S.L., COX, K., ROSEN, V. and LYONS, K.M. (2001). Bone morphogenetic protein-3 is a negative regulator of bone density. Nat Genet27: 84-8.

DELATTE, M., VON DEN HOFF, J.W., VAN RHEDEN, R.E. and KUIJPERSJAGTMAN, A.M. (2004). Primary and secondary cartilages of the neonatal rat: The femoral head and the mandibular condyle. Eur J Oral Sci112: 156-62.

DEPEW, M.J., LIU, J.K., LONG, J.E., PRESLEY, R., MENESES, J.J., PEDERSEN, R.A. and RUBENSTEIN, J.L. (1999). DIx5 regulates regional development of the branchial arches and sensory capsules. Development 126: 3831-46.

DEWULF, N., VERSCHUEREN, K., LONNOY, O., MOREN, A., GRIMSBY, S., VANDE SPIEGLE, K., MIYAZONO, K., HUYLEBROECK, D. and TEN DIJKE, P. (1995). Distinct spatial and temporal expression patterns of two type i receptors for bone morphogenetic proteins during mouse embryogenesis. Endocrinology 136: 2652-63.

DILEONE, R.J., KING, J.A., STORM, E.E., COPELAND, N.G., JENKINS, N.A. and KINGSLEY, D.M. (1997). The bmp8 gene is expressed in developing skeletal tissue and maps near the achondroplasia locus on mouse chromosome 4. Genomics 40: 196-8.

DUBE, J.L., WANG, P., ELVIN, J., LYONS, K.M., CELESTE, A.J. and MATZUK, M.M. (1998). The bone morphogenetic protein 15 gene is $x$-linked and expressed in oocytes. Mol Endocrino/12: 1809-17

DUDAS, M., SRIDURONGRIT, S., NAGY, A., OKAZAKI, K. and KAARTINEN, V. (2004). Craniofacial defects in mice lacking bmp type i receptor alk2 in neural crest cells. Mech Dev 121: 173-82.

DUDLEY, A.T., LYONS, K.M. and ROBERTSON, E.J. (1995). A requirement for bone morphogenetic protein-7 during development of the mammalian kidney and eye. Genes Dev 9: 2795-807.

DUDLEY, A.T. and ROBERTSON, E.J. (1997). Overlapping expression domains of bone morphogenetic protein family members potentially account for limited tissue defects in bmp7 deficient embryos. Dev Dyn 208: 349-62.

DUPREZ, D., BELL, E.J., RICHARDSON, M.K., ARCHER, C.W., WOLPERT, L., BRICKELL, P.M. and FRANCIS-WEST, P.H. (1996a). Overexpression of bmp2 and bmp-4 alters the size and shape of developing skeletal elements in the chick limb. Mech Dev 57: 145-57.

DUPREZ, D.M., COLTEY, M., AMTHOR, H., BRICKELL, P.M. and TICKLE, C. (1996b). Bone morphogenetic protein-2 (bmp-2) inhibits muscle development and promotes cartilage formation in chick limb bud cultures. Dev Bio/174: 44852.

EAMES, B.F. and HELMS, J.A. (2004). Conserved molecular program regulating cranial and appendicular skeletogenesis. Dev Dyn 231: 4-13.

FRANCIS-WEST, P., LADHER, R., BARLOW, A. and GRAVESON, A. (1998). Signalling interactions during facial development. Mech Dev 75: 3-28.

FRANCIS-WEST, P.H., TATLA, T. and BRICKELL, P.M. (1994). Expression patterns of the bone morphogenetic protein genes bmp-4 and bmp-2 in the developing chick face suggest a role in outgrowth of the primordia. Dev Dyn201: 168-78.

GATO, A., MARTINEZ, M.L., TUDELA, C., ALONSO, I., MORO, J.A., FORMOSO, M.A., FERGUSON, M.W. and MARTINEZ-ALVAREZ, C. (2002). Tgf-beta(3)induced chondroitin sulphate proteoglycan mediates palatal shelf adhesion.
Dev Bio/250: 393-405.

GONG, S.G. and GUO, C. (2003). Bmp4 gene is expressed at the putative site of fusion in the midfacial region. Differentiation 71: 228-36.

GRAHAM, A., FRANCIS-WEST, P., BRICKELL, P. and LUMSDEN, A. (1994). The signalling molecule bmp4 mediates apoptosis in the rhombencephalic neural crest. Nature 372: 684-6.

GU, Z., REYNOLDS, E.M., SONG, J., LEI, H., FEIJEN, A., YU, L., HE, W., MACLAUGHLIN, D.T., VAN DEN EIJNDEN-VAN RAAIJ, J., DONAHOE, P.K. et al. (1999). The type i serine/threonine kinase receptor actria (alk2) is required for gastrulation of the mouse embryo. Development 126: 2551-61.

GUHA, U., GOMES, W.A., KOBAYASHI, T., PESTELL, R.G. and KESSLER, J.A. (2002). In vivo evidence that bmp signaling is necessary for apoptosis in the mouse limb. Dev Bio/249: 108-20.

HAN, B., PERELMAN, N., TANG, B., HALL, F., SHORS, E.C. and NIMNI, M.E. (2002). Collagen-targeted bmp3 fusion proteins arrayed on collagen matrices or porous ceramics impregnated with type i collagen enhance osteogenesis in a rat cranial defect model. J Orthop Res 20: 747-55.

HELMS, J.A. and SCHNEIDER, R.A. (2003). Cranial skeletal biology. Nature 423: 326-31.

HOLLEVILLE, N., QUILHAC, A., BONTOUX, M. and MONSORO-BURQ, A.H. (2003). Bmp signals regulate dlx5 during early avian skull development. Dev Bio/257: 177-89.

HUANG, R., LANG, E.R., OTTO, W.R., CHRIST, B. and PATEL, K. (2001). Molecular and cellular analysis of embryonic avian tongue development. Anat Embryol (Berl) 204: 179-87.

INADA, M., KATAGIRI, T., AKIYAMA, S., NAMIKA, M., KOMAKI, M., YAMAGUCHI, A., KAMOI, K., ROSEN, V. and SUDA, T. (1996). Bone morphogenetic protein12 and -13 inhibit terminal differentiation of myoblasts, but do not induce their differentiation into osteoblasts. Biochem Biophys Res Commun 222: 317-22.

IOHARA, K., NAKASHIMA, M., ITO, M., ISHIKAWA, M., NAKASIMA, A. and AKAMINE, A. (2004). Dentin regeneration by dental pulp stem cell therapy with recombinant human bone morphogenetic protein 2. J Dent Res 83: 590-5.

JENA, N., MARTIN-SEISDEDOS, C., MCCUE, P. and CROCE, C.M. (1997). Bmp7 null mutation in mice: Developmental defects in skeleton, kidney and eye. Exp Cell Res 230: 28-37.

KAN, L., HU, M., GOMES, W.A. and KESSLER, J.A. (2004). Transgenic mice overexpressing bmp4 develop a fibrodysplasia ossificans progressiva (fop)-like phenotype. Am J Patho/165: 1107-15.

KANZLER, B., FOREMAN, R.K., LABOSKY, P.A. and MALLO, M. (2000). Bmp signaling is essential for development of skeletogenic and neurogenic cranial neural crest. Development 127: 1095-104.

KARSENTY, G. (1999). The genetic transformation of bone biology. Genes Dev13: 3037-51.

KARSENTY, G. (2003). The complexities of skeletal biology. Nature 423: 316-8.

KIM, H.J., RICE, D.P., KETTUNEN, P.J. and THESLEFF, I. (1998). Fgf-, bmp- and shh-mediated signalling pathways in the regulation of cranial suture morphogenesis and calvarial bone development. Development 125: 1241-51.

KING, J.A., MARKER, P.C., SEUNG, K.J. and KINGSLEY, D.M. (1994). Bmp5 and the molecular, skeletal and soft-tissue alterations in short ear mice. Dev Biol 166: 112-22.

KINGSLEY, D.M., BLAND, A.E., GRUBBER, J.M., MARKER, P.C., RUSSELL, L.B., COPELAND, N.G. and JENKINS, N.A. (1992). The mouse short ear skeletal morphogenesis locus is associated with defects in a bone morphogenetic member of the tgf beta superfamily. Cel/71: 399-410.

KISHIGAMI, S. and MISHINA, Y. (2005). Bmp signaling and early embryonic patterning. Cytokine Growth Factor Rev 16: 265-78.

KNECHT, A.K. and BRONNER-FRASER, M. (2002). Induction of the neural crest: A multigene process. Nat Rev Genet 3: 453-61.

KULESA, P., ELLIES, D.L. and TRAINOR, P.A. (2004). Comparative analysis of neural crest cell death, migration and function during vertebrate embryogenesis. Dev Dyn 229: 14-29.

LEE, K.J., MENDELSOHN, M. and JESSELL, T.M. (1998). Neuronal patterning by bmps: A requirement for gdf7 in the generation of a discrete class of commissural interneurons in the mouse spinal cord. Genes Dev 12: 3394-407.

LIEBERMAN, J.R., DALUISKI, A., STEVENSON, S., WU, L., MCALLISTER, P., 
LEE, Y.P., KABO, J.M., FINERMAN, G.A., BERK, A.J. and WITTE, O.N. (1999). The effect of regional gene therapy with bone morphogenetic protein-2-producing bone-marrow cells on the repair of segmental femoral defects in rats. JBone Joint Surg Am 81: 905-17.

LIEBERMAN, J.R., LE, L.Q., WU, L., FINERMAN, G.A., BERK, A., WITTE, O.N. and STEVENSON, S. (1998). Regional gene therapy with a bmp-2-producing murine stromal cell line induces heterotopic and orthotopic bone formation in rodents. J Orthop Res 16: 330-9.

LIEM, K.F., JR., TREMML, G., ROELINK, H. and JESSELL, T.M. (1995). Dorsal differentiation of neural plate cells induced by bmp-mediated signals from epidermal ectoderm. Cel/82: 969-79.

LIU, W., SUN, X., BRAUT, A., MISHINA, Y., BEHRINGER, R.R., MINA, M. and MARTIN, J.F. (2005). Distinct functions for bmp signaling in lip and palate fusion in mice. Development 132: 1453-61.

LOPEZ-COVIELLA, I., BERSE, B., KRAUSS, R., THIES, R.S. and BLUSZTAJN, J.K. (2000). Induction and maintenance of the neuronal cholinergic phenotype in the central nervous system by bmp-9. Science 289: 313-6.

LU, H., JIN, Y. and TIPOE, G.L. (2000). Alteration in the expression of bone morphogenetic protein-2,3,4,5 mrna during pathogenesis of cleft palate in balb/ c mice. Arch Oral Bio/45: 133-40.

LUO, G., HOFMANN, C., BRONCKERS, A.L., SOHOCKI, M., BRADLEY, A. and KARSENTY, G. (1995). Bmp-7 is an inducer of nephrogenesis and is also required for eye development and skeletal patterning. Genes Dev 9: 2808-20.

MACIAS, D., GANAN, Y., SAMPATH, T.K., PIEDRA, M.E., ROS, M.A. and HURLE, J.M. (1997). Role of bmp-2 and op-1 (bmp-7) in programmed cell death and skeletogenesis during chick limb development. Development 124: 1109-17.

MARAZZI, G., WANG, Y. and SASSOON, D. (1997). Msx2 is a transcriptional regulator in the bmp4-mediated programmed cell death pathway. Dev Bio/186: 127-38.

MCPHERRON, A.C., LAWLER, A.M. and LEE, S.J. (1997). Regulation of skeletal muscle mass in mice by a new tgf-beta superfamily member. Nature 387: 83-90.

MCPHERRON, A.C., LAWLER, A.M. and LEE, S.J. (1999). Regulation of anterior/ posterior patterning of the axial skeleton by growth/differentiation factor 11. Nat Genet 22: 260-4.

MILLER, A.F., HARVEY, S.A., THIES, R.S. and OLSON, M.S. (2000). Bone morphogenetic protein-9. An autocrine/paracrine cytokine in the liver. $J$ Bio/ Chem 275: 17937-45.

MININA, E., KRESCHEL, C., NASKI, M.C., ORNITZ, D.M. and VORTKAMP, A. (2002). Interaction of fgf, ihh/pthlh and bmp signaling integrates chondrocyte proliferation and hypertrophic differentiation. Dev Cel/3: 439-49.

MININA, E., WENZEL, H.M., KRESCHEL, C., KARP, S., GAFFIELD, W., MCMAHON, A.P. and VORTKAMP, A. (2001). Bmp and ihh/pthrp signaling interact to coordinate chondrocyte proliferation and differentiation. Development 128: 4523-34.

MISHINA, Y., CROMBIE, R., BRADLEY, A. and BEHRINGER, R.R. (1999). Multiple roles for activin-like kinase-2 signaling during mouse embryogenesis. Dev Bio/ 213: 314-26.

MISHINA, Y., SUZUKI, A., UENO, N. and BEHRINGER, R.R. (1995). Bmpr encodes a type $\mathrm{i}$ bone morphogenetic protein receptor that is essential for gastrulation during mouse embryogenesis. Genes Dev 9: 3027-37.

MUSGRAVE, D.S., PRUCHNIC, R., WRIGHT, V., BOSCH, P., GHIVIZZANI, S.C., ROBBINS, P.D. and HUARD, J. (2001). The effect of bone morphogenetic protein-2 expression on the early fate of skeletal muscle-derived cells. Bone28: 499-506.

NAKASHIMA, M. (1994). Induction of dentin formation on canine amputated pulp by recombinant human bone morphogenetic proteins (bmp)-2 and -4 . J Dent Res 73: 1515-22.

NAKASHIMA, M. and REDDI, A.H. (2003). The application of bone morphogenetic proteins to dental tissue engineering. Nat Biotechno/21: 1025-32.

NAKASHIMA, M., TOYONO, T., AKAMINE, A. and JOYNER, A. (1999). Expression of growth/differentiation factor 11 , a new member of the bmp/tgfbeta superfamily during mouse embryogenesis. Mech Dev 80: 185-9.

NAKASHIMA, M., TOYONO, T., MURAKAMI, T. and AKAMINE, A. (1998). Transforming growth factor-beta superfamily members expressed in rat incisor pulp. Arch Oral Biol 43: 745-51.
NASKI, M.C., COLVIN, J.S., COFFIN, J.D. and ORNITZ, D.M. (1998). Repression of hedgehog signaling and bmp4 expression in growth plate cartilage by fibroblast growth factor receptor 3. Development 125: 4977-88.

NEUHAUS, H., ROSEN, V. and THIES, R.S. (1999). Heart specific expression of mouse bmp-10 a novel member of the tgf-beta superfamily. Mech Dev80: 181 4

NIE, X. (2005a). Apoptosis, proliferation and gene expression patterns in mouse developing tongue. Anat Embryol (Berl) 210: 125-32.

NIE, X. (2005b). Cranial base in craniofacial development: Developmental features, influence on facial growth, anomaly and molecular basis. Acta Odontol Scand63: 127-35

NIE, X.G. (2005c). [differential expression of bmp2, bmp4 and bmp3 in embryonic development of mouse anterior and posterior palate.]. Chin Med J (Engl) 118: 1710-6.

NODEN, D.M. (1983). The embryonic origins of avian cephalic and cervical muscles and associated connective tissues. Am J Anat 168: 257-76.

NODEN, D.M. (1988). Interactions and fates of avian craniofacial mesenchyme. Development 103 Suppl: 121-40.

NOHE, A., KEATING, E., KNAUS, P. and PETERSEN, N.O. (2004). Signal transduction of bone morphogenetic protein receptors. Cell Signa/16: 291-9.

OMI, M., SATO-MAEDA, M. and IDE, H. (2000). Role of chondrogenic tissue in programmed cell death and bmp expression in chick limb buds. Int J Dev Biol 44: 381-8.

OZKAYNAK, E., SCHNEGELSBERG, P.N., JIN, D.F., CLIFFORD, G.M., WARREN, F.D., DRIER, E.A. and OPPERMANN, H. (1992). Osteogenic protein-2. A new member of the transforming growth factor-beta superfamily expressed early in embryogenesis. J Biol Chem 267: 25220-7.

RANKIN, C.T., BUNTON, T., LAWLER, A.M. and LEE, S.J. (2000). Regulation of left-right patterning in mice by growth/differentiation factor-1. Nat Genet 24: 262-5.

SATOKATA, I. and MAAS, R. (1994). Msx1 deficient mice exhibit cleft palate and abnormalities of craniofacial and tooth development. Nat Genet 6: 348-56.

SCHUELKE, M., WAGNER, K.R., STOLZ, L.E., HUBNER, C., RIEBEL, T., KOMEN, W., BRAUN, T., TOBIN, J.F. and LEE, S.J. (2004). Myostatin mutation associated with gross muscle hypertrophy in a child. N Eng/J Med350: 2682-8.

SENA, K., MOROTOME, Y., BABA, O., TERASHIMA, T., TAKANO, Y. and ISHIKAWA, I. (2003). Gene expression of growth differentiation factors in the developing periodontium of rat molars. J Dent Res 82: 166-71.

SETTLE, S., MARKER, P., GURLEY, K., SINHA, A., THACKER, A., WANG, Y., HIGGINS, K., CUNHA, G. and KINGSLEY, D.M. (2001). The bmp family member gdf7 is required for seminal vesicle growth, branching morphogenesis and cytodifferentiation. Dev Bio/234: 138-50.

SETTLE, S.H., JR., ROUNTREE, R.B., SINHA, A., THACKER, A., HIGGINS, K. and KINGSLEY, D.M. (2003). Multiple joint and skeletal patterning defects caused by single and double mutations in the mouse gdf6 and gdf5 genes. Dev Bio/254: 116-30.

SHIBATA, S., SUZUKI, S., TENGAN, T., ISHII, M. and KURODA, T. (1996). A histological study of the developing condylar cartilage of the fetal mouse mandible using coronal sections. Arch Oral Bio/41: 47-54.

SHUM, L., WANG, X., KANE, A.A. and NUCKOLLS, G.H. (2003). Bmp4 promotes chondrocyte proliferation and hypertrophy in the endochondral cranial base. Int $J$ Dev Bio/47: 423-31.

SOLLOWAY, M.J., DUDLEY, A.T., BIKOFF, E.K., LYONS, K.M., HOGAN, B.L. and ROBERTSON, E.J. (1998). Mice lacking bmp6 function. Dev Genet22: 321-39.

SOLLOWAY, M.J. and ROBERTSON, E.J. (1999). Early embryonic lethality in bmp5;bmp7 double mutant mice suggests functional redundancy within the $60 \mathrm{a}$ subgroup. Development 126: 1753-68.

STORM, E.E., HUYNH, T.V., COPELAND, N.G., JENKINS, N.A., KINGSLEY, D.M. and LEE, S.J. (1994). Limb alterations in brachypodism mice due to mutations in a new member of the tgf beta-superfamily. Nature 368: 639-43.

STORM, E.E. and KINGSLEY, D.M. (1996). Joint patterning defects caused by single and double mutations in members of the bone morphogenetic protein (bmp) family. Development 122: 3969-79.

SUZUKI, T., BESSHO, K., FUJIMURA, K., OKUBO, Y., SEGAMI, N. and IIZUKA, T. (2002). Regeneration of defects in the articular cartilage in rabbit temporo- 
mandibular joints by bone morphogenetic protein-2. Br J Oral Maxillofac Surg 40: 201-6.

TAKAHASHI, K., NUCKOLLS, G.H., TANAKA, O., SEMBA, I., TAKAHASHI, I., DASHNER, R., SHUM, L. and SLAVKIN, H.C. (1998). Adenovirus-mediated ectopic expression of $\mathrm{msx} 2$ in even-numbered rhombomeres induces apoptotic elimination of cranial neural crest cells in ovo. Development 125: 1627-35.

TEIXEIRA FILHO, F.L., BARACAT, E.C., LEE, T.H., SUH, C.S., MATSUI, M., CHANG, R.J., SHIMASAKI, S. and ERICKSON, G.F. (2002). Aberrant expression of growth differentiation factor-9 in oocytes of women with polycystic ovary syndrome. J Clin Endocrinol Metab 87: 1337-44.

TRAINOR, P.A., MELTON, K.R. and MANZANARES, M. (2003). Origins and plasticity of neural crest cells and their roles in jaw and craniofacial evolution. Int J Dev Bio/47: 541-53.

TRIBULO, C., AYBAR, M.J., NGUYEN, V.H., MULLINS, M.C. and MAYOR, R. (2003). Regulation of msx genes by a bmp gradient is essential for neural crest specification. Development 130: 6441-52.

TZAHOR, E., KEMPF, H., MOOTOOSAMY, R.C., POON, A.C., ABZHANOV, A., TABIN, C.J., DIETRICH, S. and LASSAR, A.B. (2003). Antagonists of wnt and bmp signaling promote the formation of vertebrate head muscle. Genes Dev17: 3087-99.

URIST, M.R. (1965). Bone: Formation by autoinduction. Science 150: 893-9.

VAINIO, S., KARAVANOVA, I., JOWETT, A. and THESLEFF, I. (1993). Identification of bmp-4 as a signal mediating secondary induction between epithelial and mesenchymal tissues during early tooth development. Cel/75: 45-58.

WALL, N.A., CRAIG, E.J., LABOSKY, P.A. and KESSLER, D.S. (2000). Mesendoderm induction and reversal of left-right pattern by mouse gdf1, a vg1related gene. Dev Bio/227: 495-509.

WILSON, J. and TUCKER, A.S. (2004). Fgf and bmp signals repress the expression of bapx 1 in the mandibular mesenchyme and control the position of the developing jaw joint. Dev Bio/266: 138-50.

WINNIER, G., BLESSING, M., LABOSKY, P.A. and HOGAN, B.L. (1995). Bone morphogenetic protein- 4 is required for mesoderm formation and patterning in the mouse. Genes Dev 9: 2105-16.

WOZNEY, J.M., ROSEN, V., CELESTE, A.J., MITSOCK, L.M., WHITTERS, M.J., KRIZ, R.W., HEWICK, R.M. and WANG, E.A. (1988). Novel regulators of bone formation: Molecular clones and activities. Science 242: 1528-34.

YAMASHIRO, T., TUMMERS, M. and THESLEFF, I. (2003). Expression of bone morphogenetic proteins and msx genes during root formation. J Dent Res 82 : 172-6.

YI, S.E., DALUISKI, A., PEDERSON, R., ROSEN, V. and LYONS, K.M. (2000). The type i bmp receptor bmprib is required for chondrogenesis in the mouse limb.
Development 127: 621-30.

YOKOUCHI, Y., SAKIYAMA, J., KAMEDA, T., IBA, H., SUZUKI, A., UENO, N. and KUROIWA, A. (1996). Bmp-2/-4 mediate programmed cell death in chicken limb buds. Development 122: 3725-34.

YOON, B.S. and LYONS, K.M. (2004). Multiple functions of bmps in chondrogenesis. J Cell Biochem 93: 93-103.

ZHANG, H. and BRADLEY, A. (1996). Mice deficient for bmp2 are nonviable and have defects in amnion/chorion and cardiac development. Development 122: 2977-86.

ZHANG, Y., ZHANG, Z., ZHAO, X., YU, X., HU, Y., GERONIMO, B., FROMM, S.H. and CHEN, Y.P. (2000). A new function of bmp4: Dual role for bmp4 in regulation of sonic hedgehog expression in the mouse tooth germ. Development 127: 1431-43.

ZHANG, Z., SONG, Y., ZHANG, X., TANG, J., CHEN, J. and CHEN, Y. (2003). Msx1/bmp4 genetic pathway regulates mammalian alveolar bone formation via induction of dlx5 and cbfa1. Mech Dev 120: 1469-79.

ZHANG, Z., SONG, Y., ZHAO, X., ZHANG, X., FERMIN, C. and CHEN, Y. (2002). Rescue of cleft palate in msx1-deficient mice by transgenic bmp4 reveals a network of bmp and shh signaling in the regulation of mammalian palatogenesis. Development 129: 4135-46.

ZHAO, G.Q., LIAW, L. and HOGAN, B.L. (1998). Bone morphogenetic protein 8a plays a role in the maintenance of spermatogenesis and the integrity of the epididymis. Development 125: 1103-12.

ZHAO, M., HARRIS, S.E., HORN, D., GENG, Z., NISHIMURA, R., MUNDY, G.R. and CHEN, D. (2002). Bone morphogenetic protein receptor signaling is necessary for normal murine postnatal bone formation. J Cel/ Bio/157: 1049-60.

ZHAO, P. and HOFFMAN, E.P. (2004). Embryonic myogenesis pathways in muscle regeneration. Dev Dyn 229: 380-92.

ZHAO, R., LAWLER, A.M. and LEE, S.J. (1999). Characterization of gdf-10 expression patterns and null mice. Dev Bio/212: 68-79.

ZHAO, X., ZHANG, Z., SONG, Y., ZHANG, X., ZHANG, Y., HU, Y., FROMM, S.H. and CHEN, Y. (2000). Transgenically ectopic expression of bmp4 to the msx1 mutant dental mesenchyme restores downstream gene expression but represses shh and bmp2 in the enamel knot of wild type tooth germ. Mech Dev99: 29-38.
Received: September 2005

Reviewed by Referees: November 2005

Modified by Authors and Accepted for Publication: March 2006

Online Publication: April 2006 